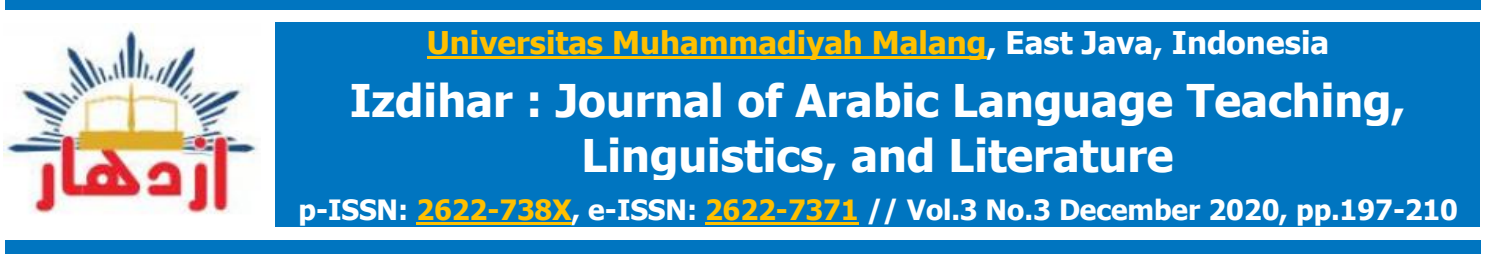

doi

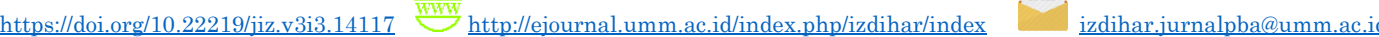

\title{
Teacher's Perception toward the Readiness to Face Multiculturalism in Arabic Teaching and Learning
}

\author{
Noza Aflisiaa, 1 , Mohamad Erihadiana ${ }^{b, 2}$ Nur Balqis $^{c, 3}$ \\ anstitut Agama Islam Negeri Curup, Indonesia \\ bUniversitas Islam Negeri Sunan Gunung Djati Bandung, Indonesia, \\ cUniversitas Liga Arab, Mesir
}

1nozaaflisia@iaincurup.ac.id, ${ }^{2}$ erihadiana@uinsgd.ac.id, ${ }^{3}$ nurbalqis58@gmail.com

\section{ARTICLE INFO}

\section{Article History:}

Received: 30/10/2020

Revised: $07 / 12 / 2020$

Accepted: $31 / 12 / 2020$

Published: $31 / 12 / 2020$

\section{*Corresponding}

Author:

Name: Noza Aflisia

Email:

nozaaflisia@iaincurup.ac.id

\section{Keyword}

\section{ABSTRACT}

Multicultural presence required an appropriate response from Arabic teachers, so that Arabic is easily accepted and loved by various groups. This research aimed to analyze the efforts of Arabic teachers in dealing with multiculturalism and analyze the obstacles encountered in applying multicultural education in Arabic language learning. This qualitative descriptive research was conducted with interview and documentation. While the data analysis and processing techniques used in this study were processing and preparing the data for analysis, reading the entire data, starting coding all the data, coding to explain the settings, people, categories, themes analyzed, and describing the themes that will be presented again in the narrative/qualitative report. The results revealed that the efforts of Arabic teachers to confront multicultural were by reaffirming the unifying Arabic for Muslims, confirming Arabic as one of the International languages, learning the essence of multicultural, improving didactic and methodical competencies, attending training, and modeling. The constraints of the application of multicultural education in Arabic language learning were lack of understanding of the essence of multicultural, lack of knowledge of learning methods and strategies, lack of literature, lack of syllabus and teaching materials contained multicultural education, lack of support from institutions, and lack of training and guidance Copyright (c) 2020, Aflisia et al This is an open access article under the CC-BY-SA license

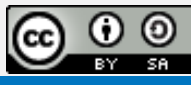

Arabic Language; Learning; Multiculturalism; Teacher; Teaching

\section{مستخلص البحث}

تطلب تواجد التعدد الثقافي استجابة مناسبة من معلمي اللغة العربية، حتى قبول اللغة العربية بسهولة، وتحهها المجموعات المختلفة. هدف هذا

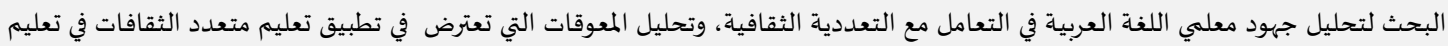

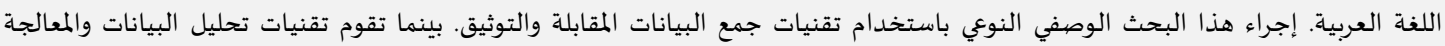

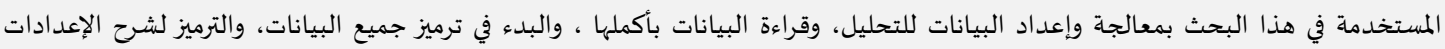

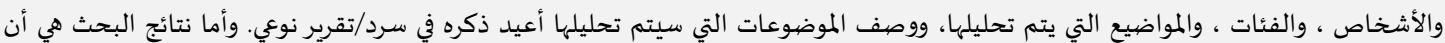

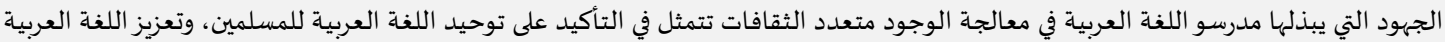

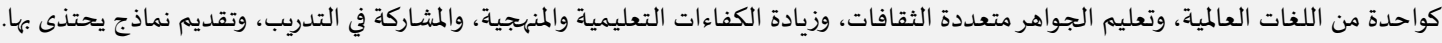
وأما العوائق في تطبيق تعليم متعدد الثقافات في تعليم اللغة العربية هي عدم فهم جوهر التعددية الثقافية، ونقص المعرفة بأساليب واستراتيجيات

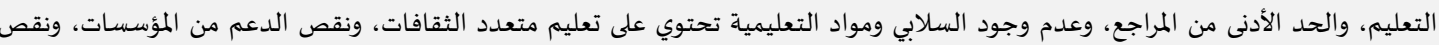
التدربب والتوجياه. 


\section{INTRODUCTION}

Multicultural is the diversity in cultures that are owned by a person and a place. Multicultural education is education that raises an awareness of the differences and diversity of cultures, ethnices, races, and religions that are owned by each region and individuals that must be responded to with wisdom. Azra explains that multicultural education as a substitute for intercultural education is expected to foster a caring attitude and willingness to understand or the existence of a political recognition of human culture such as tolerance, ethnocultural and religious differences, discrimination, human rights, democracy and plurality, universal humanity and other subjects. which is relevant (Suryana \& Rusdiana, 2015). Multicultural education is a process of developing all human potential that respects plurality and heterogeneity as a consequence of cultural, ethnic, ethnic and religious diversity (Winata, Ruswandi, \& Erihadiana, 2020).

Other countries such as Japan, multicultural interactions occur in various types of space: first, spaces that are not meant for multicultural interactions, but there are multicultural interactions; second, a space that is deliberately designed for multicultural interactions, and third, a space for policy (Tsuneyoshi \& Okano, 2010).

In America, multicultural education is a context for teaching that is responsive to culture, namely education that changes school practices that differentiate the treatment of students (Koppelman, 2011). The fields of education, politics, and economy were dominated by white people, which eventually sparked a conflict demanding equal rights as citizens by people of color (Masunah, 2011). In Wyoming, Casper is a region of the United States. This multicultural education approach can easily minimize the cultural and racial isolation experienced in predominantly white rural Early Childhood programs, giving children the opportunity to obtain credible and objective information about the cultural differences they see (Nganga, 2015). Based on this, multicultural education becomes something very important and urgent to be implemented in the praxis of education, including in Indonesia (Baharun \& Awwaliyah, 2017).

Multicultural in Indonesia is written in the slogan of the State "Bhinneka Tunggal Ika" although it is different but still one. The State of Indonesia is a country where most of its territory consists of waters with various islands and regions having their respective cultures. Life in a pluralistic society with various cultures owned, ethnic groups, and religions requires a wise way of addressing such diversity and differences.

Before the presence of multicultural in education, previously there was the Melting Pot, which is a fusion that is basically the same as the principle of democracy by combining all differences into a culture. Then comes the Salad Bowl, where all people who have differences can live side by side with their 
respective cultures. However, these two concepts have not been able to achieve their maximum goals. Multiculturalism exists to deal with both (Agustian, 2019). After the presence of multiculturalism, it takes a national education management that can accommodate the concept of multicultural education (Nurcholis, 2019).

The diversity that is present in society reflects the same situation in the field of education. Education, which is essentially the process of raising students' awareness of the value of goodness, so that with this kindness they can behave well and correctly which is also supported by the environment. Education becomes a place to transfer the value of goodness to students through the learning process and the attitude of the teacher. Parties involved in learning become subjects and objects of multicultural application in education, especially learning.

Application of multicultural in learning does not have to be done by forming a special subject for Multicultural Education, but is done by integrating it in various existing subjects. Whether it's Mathematics, Islamic Religious Education, Citizenship, and so on. In mathematics learning, multicultural education is developed through five elements of multicultural education expressed by James Banks, namely First, integrating culture in the content of mathematics lessons, Second, constructing mathematical knowledge through existing cultural contexts and understanding, Third, pedagogic equality, Fourth reducing prejudice, and Fifth, empowering a conducive school culture (Danoebroto, 2013). In Islamic Religious Education, cultural material can be developed with Al-Quran material content related to the Al-Quran recognition of diversity and social coexistence in interactions between religious communities. The Jurisprudence material was expanded with studies related to siyasa. Moral material focuses on morals towards Allah, Rasul, fellow humans, the environment, and morals towards oneself. The SKI material again reminds the history of how social relations were applied by the Prophet when he built civilization in Medina after he left the city of Mecca (Muliadi, 2011). Religious education that has a multicultural perspective will cover all possibilities for discrimination on the grounds of differences in religion, culture, ethnicity, and so on (Sapsuha, 2013).

Application of multicultural education in learning Citizenship is carried out by presenting material regarding the individual rights and collective rights of every member of society, namely that all members are free to create and work in order to develop their culture, uphold justice and minority rights, freedom to express opinions, to represent their aspirations in governance or legislative structures, and tolerance (Dwintari, 2018). The approaches that can be applied in early childhood education are the contribution approach and the additive approach (Fadlillah, 2017). Brainstorming or the exchange of ideas and the 
implementation of activities such as seminars, talk shows, workshops, research, training and so on are among the options in implementing a multicultural development strategy (Fajrussalam, Ruswandi, \& Erihadiana, 2020).

In addition to integrating multicultural education in various science, social, and religious subjects as previously mentioned, the integration of multicultural education also occurs in language subjects. In learning Indonesian Language Skills, the material provided to students is related to the realities of life that occur in society, then students are expected to be able to convey ideas through the material text that has been given (Zulaeha, 2013).

Foreign Language is also inseparable from the object of integrating multicultural education in learning. Foreign languages have an equally large role in instilling multicultural awareness, both English and Arabic. Positive attitudes of students and teachers towards multiculturalism, together with their respect and acceptance of diversity, foster a healthy and safe learning environment that enables multicultural collaboration (Donoso, Ortega, \& Castillo, 2020). By learning local, national and international cultures, acts of violence in the name of differences in language and culture can be minimized.

Arabic learning by integrating multicultural education has begun to be studied by Arabic experts. Through the revitalization of the role of Arabic, believed to be able to overcome conflict in a multicultural perspective (Isnaini, 2018). Arabic education based multicultural emphasizes moral values, compassion, love for others, help each other, tolerance, respect for diversity and other attitudes that uphold humanity (Qomaruddin, 2019). In addition, multicultural education has become part of regular education in pesantren for three main reasons: (1) the social reality of Indonesian society (2) the influence of culture and ethnicity on human growth, and (3) the development, and conditions of effective teaching, and learning (Bukhori, 2019). To implement multicultural education in Arabic learning, it can be done at maharah istima' kalam, qiroah, and Kitabah (Rifa'i, 2015).

Integrating multicultural education in Arabic learning is important so that Arabic is easily accepted, there is a sense of solidarity and Arabic is loved by various groups without any distinction between the cultural backgrounds of students. So that by itself people will recognize the religion of Islam Rahmah li al-'Alamin. Achieving all of this is not an easy job to do, it requires strong intentions, adequate knowledge of the essence and implementation of multicultural education and commitment in carrying it out. Various efforts need to be made and become a measure of the readiness of Arabic teachers in facing multicultural presence in the community.

Different from several previous studies that have been described regarding multicultural in various scientific disciplines, it provides an overview of 
the implementation of multicultural education in the general field of study, while the studies conducted by researchers described the problems of Arabic teachers related to multiculturalism so that solutions can be found in dealing with them.

This study aimed to analyze (1) the efforts of Arabic teachers in confront multicultural, and (2) constraints of multicultural education implementation in Arabic learning. With the knowledge of the teacher's efforts and the constraints, it is hoped that the right solutions will be found and be able to become a reference for Arabic practitioners in making innovations in Arabic learning amidst the diversity of students.

\section{METHOD}

Type of research was descriptive qualitative. Researchers chose this method because the data obtained by researchers in the field were generally expressed in verbal form and in descriptive analysis. Miles \& Huberman in Creswell explained that qualitative research can be understood as an investigative process in which researchers slowly interpret a social phenomenon by distinguishing, comparing, evaluating, cataloging, and classifying research objects (Cresswell, 2014). Sources of data were obtained from Arabic teachers in Jambi Province, Indonesia who have many schools that study Arabic as a field of study. Meanwhile, secondary data were obtained from various articles and books related to multicultural.

The data collection techniques used in this study were interviews and documentation. While the data analysis and processing techniques used in this study were processing and preparing the data for analysis, reading the entire data, starting coding all the data, coding to explain the settings, peoples, categories and themes being analyzed, and describing the themes that will be restated in the narrative/qualitative report (Cresswell, 2014).

\section{RESULTS \& DISCUSSION}

\section{The Efforts of Arabic Teachers in Confront Multicultural}

The presence of multicultural today makes teachers, especially Arabic teachers, have to accept and adapt to its existence. The readiness needed is not only readiness to apply it but the main thing is self-preparedness and mental readiness. There are several types of people when responding to something new that becomes change or innovation, namely: first, early adapters are people who immediately accept change. Second, early majority are people who acknowledge the need for change but do not immediately accept it/learn first. Third, undecided 
are the people waiting for the direction of the wind to blow. Fourth, the late majority are people who are anxious about the developing condition, especially the effect of change will have on them. Fifth, late adapters are those who openly resist change. It is believed that resistance circles will always be in the process of change (Salimah, 2013).

Likewise, Arabic teachers respond to multicultural presence in learning. Some teachers do not agree with multicultural integration in Arabic learning, this is because the understanding of multicultural is not sufficient as well as its implementation in learning the strategy is not yet known. There are various ways and efforts that can be made by Arabic teachers in confront multicultural presence:

\section{First: Reaffirming the Unifying Arabic Language for Muslims}

There is a reaffirmation of the importance of Arabic as the language of Islam which has an important substance in teaching the values of goodness, especially regarding awareness multicultural as contained in the Al-Quran and Hadis. In line with the essence of multiculturalism, namely the attitude of tolerance between religions, mutual respect, non-discrimination, and maintaining unity and integrity.

Multicultural religious value is a very important value to be internalized in students. With these values, it is able to make students have a tolerant and religious attitude, and be able to carry out religious teachings, touch the affections and psychomotor that they have (Rifa'i, 2016).

The essence of multicultural education does not conflict with Islam and the philosophy of the Indonesian State. Islam is a religion that believes in One Almighty God, as well as Indonesia as stated in the first precepts of Pancasila. Pancasila is the basis of the Indonesian State and the basis for the administration of law in Indonesia. Multicultural education that is centered on Indonesian character can be carried out by forming mindsets, attitudes and actions, as well as habituation so that there is a national awareness that has character (Najmina, 2018).

\section{Second: Confirming Arabic as One of the International Language}

Arabic language as an international language was declared by the United Nations (UN). Arabic has had a profound influence on other languages of the world, socially, culturally, religiously or economically (Mahmoud-Mukadam \& Adebisi, 2019). For this reason, the paradigm which states that Arabic has not been able to bridge multicultural conflicts must be resolved (Isnaini, 2018). With this reaffirmation of the position of Arabic as one of the international languages, it must be used in accordance with the provisions of Arabic fusha. The use of 
Arabic Fusha will minimize the use of Arabic 'Ammiyah and unite all Arabic users in the world, so that disputes caused by the use of the language will be avoided.

\section{Third: Learning the essence of multicultural}

The presence of something new is not immediately accompanied by a clear and correct understanding of it. It took a long time to adapt and understand the nature of multiculturalism that has colored the world, especially the world of education. As an Arabic teacher, the basic thing that must be done before the implementation stage of learning is to understand the essence of multicultural. If this stage has been carried out well, the next stage will take place without encountering many obstacles.

\section{Fourth: Improving Didactic Competence}

Didactic is a science that explains good teaching methods so that the material presented can be accepted and absorbed properly by students. The discussion contained in the didactic is how to arrange learning materials such as curriculum, syllabus, and the material to be taught. The learning materials are directed at achieving awareness of tolerance and understanding of diverse cultures. The material content offered contains themes of various cultures, ethnicities, races, religions, schools of thought, art, and so on. The content of a theme like this can be applied in four Arabic language skills, namely Maharah Istima', Kalam, Qiraah, and Kitabah so that they are reflected in the minds of students about the many differences that each country, region and individual has. Students will be familiar with differences and diversity and can position themselves in addressing diversity wisely.

Fifth, Increasing Methodic Competence

Methodic is a strategy to teach a certain type of material in detail. Methodic is more specific than didactic. Methodic discussions are related to the methods applied in teaching lessons to students, such as management of learning strategies in multicultural education. Providing motivation in learning, because every motivation has effectiveness in shaping human behavior (Rusady, 2018). Multicultural education cannot be applied properly if the administrators are teachers who do not have expertise in this field. The right strategy will get satisfactory results in learning.

There are several teacher criteria needed in developing multicultural learning, namely (1) having good skills teacher, understanding, and practice, as well as cultural values, (2) always reflecting on oneself, (3) enriching knowledge related to multicultural concepts, (4) knowing the history, characteristics, and internal differences of a culture, (5) being able to analyze comparative theories in managing diversity (Rosyada, 2014). 
Sixth: Attending Training on the Application of Multicultural Education in Arabic Learning

To be skilled in integrating multicultural education in various subjects, it is not enough just to learn self-taught, read books and ask fellow teachers. It needs training and guidance so that what is implemented is implemented effectively and the desired goals can be achieved. The training referred to is the implementation of seminars, workshops, training and so on.

\section{Seventh: Modelling}

Before a value is passed on to others, starting with yourself is the right way. Addressing diversity in a way of kindness is not enmity. To apply this to students, whether integrated in Arabic teaching material, or contained in the direction of the attitudes and behavior of students, the first to apply this is the Arabic teacher himself.

A person's language attitude will determine his ability to master the language (Riani, 2012). The attitude that multicultural education wants is to understand diversity and respond without hostility. Tolerance, mutual respect, accept the understanding and opinions of others, if there is a dispute in the opinion resolved without violence. In relation to the school environment, this is the responsibility of the teacher in building a sense of multiculturalism. Teachers as role models or examples in their application in behavior and attitudes. The teacher creates a comfortable learning atmosphere, does not discriminate between students and each other.

\section{Constraints of Multicultural Education Implementation in Arabic Learning}

Application of multicultural education in various subjects at schools has encountered several obstacles that have become obstacles to its implementation. Information obtained from some Arabic teachers stated that these constraints were:

\section{First: Less Understanding of Multicultural Essences}

To implement a learning model, it is inevitable for a teacher to know well the learning model to be applied so that learning can be carried out effectively and efficiently and the objectives to be achieved from the implementation of this learning model can be achieved properly. Likewise, with the application of multicultural education in learning, namely understanding well. However, not all Arabic teachers understand well the nature of multiculturalism and its development strategy in the Arabic language learning process. The lack of understanding of Arabic language teachers towards multicultural education is a major obstacle in its implementation. 


\section{Second: Lack of Knowledge of Learning Methods and Strategies}

When the essence of multiculturalism is well understood, then finding an appropriate method and strategy so that the desired goals are achieved. With the right method, the learning process will take place effectively and efficiently (Aflisia, 2016). The application of methods in integrating multicultural education in learning can be done by combining various methods and not sticking to one method (Ashadi, 2017). Mistakes in choosing a method have an impact on the effectiveness of learning, namely the learning atmosphere is not conducive and the material is not conveyed well to students.

\section{Third: Lack of Literature}

Books that talk about multicultural education are needed as a reference in understanding the concept and implementation of multicultural education in learning Arabic. In addition, scientific articles and research reports related to multicultural education are also indispensable. Although at present, there are quite a lot of related literature, but not with specific references to discuss the integration of multicultural education in Arabic language learning. Likewise, there are no Arabic language teaching materials based on multicultural education, both related to Arabic components such as Ashwat, Mufradat, and Tarakib, as well as Arabic language skills such as listening, speaking, reading, and writing skills.

Fourth: Unavailability of syllabus and materials containing multicultural education.

Teaching Planning for the implementation of Arabic learning that takes place in the learning classroom, must first be prepared by the teacher. Based on the data and information obtained, until now almost all Arabic teachers do not have a syllabus and teaching materials that integrate multicultural education in them. They argued, because there was no central emphasis on compiling a syllabus and teaching materials related to multicultural education in learning Arabic.

The reality of the Arabic material presented is more ideological, doctrinal, and seems indifferent to humanitarian and multicultural problems. Currently students are faced with a life of diversity from various aspects, which really need the formation of attitudes to deal with it (Rifa'i, 2015).

\section{Fifth: Lack of Support from Institutions}

The application of multicultural education in the learning process contained in an institution will relate to the institution that houses the institution where the learning takes place. The government or institution must have a strong desire to carry out clear and directed politics and take sides with the interests of the integrity of the nation based on the awareness that our nation has diversity (Ambarwangi, 2013). Support from leaders and officials of the institution also affects the ongoing application of multicultural education in learning. Support referred to is not only material support but also immaterial, namely motivation, 
support and encouragement from the leadership of the institution. In some institutions the support from the leadership has not been felt. Leaders seem indifferent and do not care about the application of multicultural education in learning Arabic. For example, there is no specific policy that emphasizes the integration of multicultural education in Arabic learning and there has been no encouragement for Arabic teachers to compile syllabus and teaching materials that are suitable for this multicultural education.

\section{Sixth: Lack of Training and Guidance}

Apart from understanding, training and guidance related to multicultural integration in learning Arabic is absolutely necessary. Training is needed to improve the performance of Arabic teachers in providing Arabic lessons to students (Aflisia \& Yasmar, 2018). Something that is applied by professionals in the field will get better results than those that are not done by professionals. In order for Arabic teachers to be skilled in implementing multiculturalism in Arabic learning, training and guidance are needed such as seminars, training, mentoring, workshops, preparing professional facilitators and tutors, and related discussions in the Arabic Language Subject Teacher Conference, Working Group Arabic teacher.

Various efforts made in addressing the presence of multiculturalism absolutely need to be done, so that friction does not occur and negative things appear undesirable. Multicultural education as one of the solutions to problems caused by the impact of globalization (Arifin, 2012). The urgency of multicultural education can bring a transformative and dialogical atmosphere to diversity (Noorhayati, 2017). The implementation of multicultural education in classroom learning can be seen from the content of multicultural materials inserted in Arabic teaching materials. The material is istima', kalam, qira'ah, and kitabah (Rifa'i, 2015), in addition, through internalization and value planting in every learning activity, such as the moral values of compassion for others, help, tolerance, respect diversity and attitudes that uphold other humanity (Qomaruddin, 2019). So that conflict in the name of various social realities, diverse cultural influences, and teaching and learning conditions (Bukhori, 2019) can be overcome by the proper teacher development and expertise in dealing with this multicultural. Both were done by affirming Arabic as a unifying language and international language, deep understanding of multicultural essence, improvement of didactic and methodic competencies, attending training, and being a true modeling in multicultural education.

Similarly, the analysis of the constraints of the application of multicultural education in Arabic learning becomes a reference to improve the quality of Arabic language learning and the performance of Arabic teachers in the future. Facing a diverse life from various aspects requires the formation of attitudes to deal with 
it (Rifa'i, 2015). Problems related to lack of understanding and ability of teachers, lack of reference books, lack of learning and training tools, and support from various parties are priorities to find a solution.

Realizing a professional Arabic teacher who is able to address social realities and is able to carry out, the teacher duties charged to him can be carried out well (Maswani \& Susiawati, 2017), if success in facing multiculturalism is achieved. While the ability in teacher assignments can be seen from the ability to plan teaching and learning programs, the ability to carry out or manage the teaching and learning process, and the ability to assess the learning process.

\section{CONCLUSIONS}

The readiness of Arabic teachers to confront multicultural can be seen from the efforts that have been made and the obstacles faced in the application. The integration of multicultural education in Arabic language learning still requires a lot of attention, seriousness, and commitment in carrying it out. So that the desired goal of implementing multicultural education can be achieved, namely having an awareness of diversity, mutual respect and tolerance in the midst of this diversity. The results of this study open space for the next researchers to look more deeply about the integration of multicultural education in learning Arabic through the development of an Arabic language curriculum based on multicultural education so that multicultural education in learning Arabic is not only a discourse and concept but practical and implementation.

\section{ACKNOWLEDGMENT}

We are grateful to the Arabic teacher who has provided information related to this research and to all parties for their support so that this research can be completed on time.

\section{BIBILIOGRAPHY}

Aflisia, N. (2016). Manhaju Ta'liymu lughoh fi Ma'had Abdurrahman bin 'auf bijama'ati Muhammadiyah Malang. El-Hekam, 1(1), 147-155. DOI: https://doi.org/10.31958/jeh.v1i1.344.

Aflisia, N., \& Yasmar, R. (2018). Upaya Meningkatkan Kemampuan Bahasa Arab Dosen Non Pendidikan Bahasa Arab. Ihayul Arabiyah, 2(2), 157-171. DOI: https://doi.org/10.31118/jeh.v1i1.322.

Agustian, M. (2019). Pendidikan Multikultural. Jakarta: Universitas Atma Jaya. 
Ambarwangi, S. (2013). Pendidikan Multikultural di Sekolah Melalui Pendidikan Seni Tradisi. Harmonia: Journal of Arts Research and Education, 13(1). 78-85. DOI: https://doi.org/10.15294/harmonia.v13i1.2535.

Arifin, Z. (2012). Pendidikan multikultural-religius untuk mewujudkan karakter peserta didik yang humanis-religius. Jurnal Pendidikan Islam, 1(1), 89106. DOI: https://doi.org/10.14421/jpi.2011.11.89-103.

Ashadi, W. (2017). Pendidikan Agama Islam Berperspektif Multikultural (Studi di Sekolah Dasar Tumbuh 1 Yogyakarta). Ta'dib: Jurnal Pendidikan Islam, 6(1), 93-100. DOI: https://doi.org/10.29313/tjpi.v6i1.2537.

Baharun, H., \& Awwaliyah, R. (2017). Pendidikan Multikultural dalam Menanggulangi Narasi Islamisme di Indonesia. Jurnal Pendidikan Agama Islam (Journal of Islamic Education Studies), 5(2), 224-243. DOI: https://doi.org/10.15642/jpai.2017.5.2.224-243.

Bukhori. (2019). Pendekatan multikultural dalam pengajaran bahasa arab di pesantren. Kelola; Jurnal IImu Sosial, 2(2), 108-128. DOI: https://doi.org/https://doi.org/10.15575/jk.v2i2.6664.

Cresswell, J. W. (2014). Research Design - Pendekatan Metode Kualitatif, Kuantitatif, dan Campuran. Yogyakarta: Pustaka Pelajar.

Danoebroto, S. W. (2013). Model Pembelajaran Matematika Berbasis Pendidikan Multikultural. Jurnal Pembangunan Pendidikan: Fondasi Dan Aplikasi, 1(1). 94-107. DOI: https://doi.org/10.21831/jppfa.v1i1.1054.

Donoso, A., Ortega, K., \& Castillo, P. A. P. (2020). Understanding the meaning of multicultural collaboration in a public-school EFL class. International Journal of Multicultural Education, 22(1), 1-15. DOI: https://doi.org/10.18251/ijme.v22i1.1929.

Dwintari, J. W. (2018). Urgensi Pendidikan Kewarganegaraan Berbasis Multikultural dalam Pembinaan Keberagaman Masyarakat Indonesia. Jurnal Ilmu Pendidikan PKn Dan Sosial Budaya, 2(1), 69-81. Retrieved from http://194.59.165.171/index.php/CC/article/download/68/112

Fadlillah, M. (2017). Model kurikulum pendidikan multikultural di taman kanakkanak. Jurnal Pembangunan Pendidikan: Fondasi Dan Aplikasi, 5(1), 4251. DOI: https://doi.org/10.21831/jppfa.v5i1.13286.

Fajrussalam, H., Ruswandi, U., \& Erihadiana, M. (2020). Strategi Pengembangan Pendidikan Multikultural di Jawa Barat. Edueksos: Jurnal Pendidikan Sosial \& Ekonomi, 9(1). 73-86. DOI: https://doi.org/10.24235/edueksos.v9i1.6385.

Isnaini, R. L. (2018). Revitalisasi Peran Bahasa Arab untuk Mengatasi Konflik dalam Perspektif Multikultural. Jurnal Pembangunan Pendidikan: Fondasi dan Aplikasi, 6(1). 15-16. DOI: https://doi.org/10.30762/empirisma.v24i2.20

Koppelman, K. L. (2011). Understanding Human Differences: Multikultural 
Education for a Diverse America (5th ed.). San Francisco: Pearson.

Mahmoud-Mukadam, A.-R., \& Aliy Adebisi, A. (2019). Language Borrowing between Arabic and Yoruba Language. Izdihar: Journal of Arabic Language Teaching, Linguistics, and Literature, 2(1), 53-66. DOI: https://doi.org/10.22219/jiz.v2i1.7386.

Masunah, J. (2011). Konsep dan praktik pendidikan multikultural di amerika serikat dan indonesia. Jurnal IImu Pendidikan, 17, 298-306. DOI: http://dx.doi.org/10.17977/jip.v17i4.2732.

Maswani, M., \& Susiawati, W. (2017). Kompetensi Profesional Guru Bahasa Arab Madrasah Aliyah (MAN) di Jakarta. Arabiyat: Jurnal Pendidikan Bahasa Arab Dan Kebahasaaraban, 4(2), 185-203. DOI: https://doi.org/10.15408/a.v4i2.6290.

Muliadi, E. (2011). Urgensi pembelajaran Pendidikan Agama Islam berbasis multikultural di sekolah. Jurnal Pendidikan Islam, 1(1), 55-70. DOI: https://doi.org/10.14421/jpi.2011.11.55-68.

Najmina, N. (2018). Pendidikan Multikultural Dalam Membentuk Karakter Bangsa Indonesia. JUPIIS: JURNAL PENDIDIKAN ILMU-ILMU SOSIAL, 10(1), 5256. DOI: https://doi.org/10.24114/jupiis.v10i1.8389.

Nganga, L. (2015). Multicultural Curriculum in Rural Early Childhood Programs. Journal of Praxis in Multicultural Education, 9(1), 2-19. DOI: https://doi.org/10.9741/2161-2978.1073.

Noorhayati, S. M. (2017). Pendidikan Multikultural di Pesantren (Upaya Membendung Radikalisme di Indonesia). MADANIA: JURNAL KAJIAN KEISLAMAN, 21(1), 67-78. DOI: https://doi.org/10.29300/madania.v21i1.212.

Nurcholis, D. (2019). Transformasi Pendidikan Multikultural di Sekolah. Jawa Timur: Abimanyu.

Qomaruddin, F. (2019). Pendidikan Bahasa Arab Berbasis Multikultural. In MIYAH: Jurnal Studi Islam. 12(2). 77-86. DOI: http://dx.doi.org/10.33754/miyah.v12i2.116.g126.

Riani. (2012). Permasalahan dalam Perencanaan Bahasa pada Masyarakat Multikultural. In Madah (Vol. 3). Retrieved from https://www.neliti.com/publications/235649/permasalahan-dalamperencanaan-bahasa-pada-masyarakat-multikultural

Rifa'i, A. (2015). Pendidikan Islam dan Bahasa Arab Multikultural di Madrasah. EMPIRISMA: Jurnal Pemikiran dan Kebudayaan Islam, 24(2). 199-213. DOI: https://doi.org/10.30762/empirisma.v24i2.20

Rifa'i, M. K. (2016). Internalisasi Nilai-nilai Religius Berbasis Multikultural dalam Membentuk Insan Kamil. Jurnal Pendidikan Agama Islam (Journal of Islamic Education Studies), 4(1), 116-133. DOI: https://doi.org/10.15642/pai.2016.4.1. 
Rosyada, D. (2014). Pandangan Multikultural di Indonesia Sebuah Pandangan Konsepsional. SOSIO DIDAKTIKA: Social Science Education Journal, 1(1). 1-12. DOI: https://doi.org/10.15408/sd.v1i1.1200.

Rusady, A. T. (2018). Dawafi' Ath-Thullab fi Ta'allum Al-Lughah Al-Arabiyyah wa Daur Al-Mu'allim fi Tarqiyatiha. IZDIHAR, 1(1), 65-78. DOI: https://doi.org/10.22219/izdihar.v1i1.6563.

Salimah, S. (2013). Analisis Pemahaman dan Kesiapan Guru Mengimplementasikan Kurikulum 2013. Retrieved from http://repository.uinsu.ac.id/1184/1/hasil Penelitian analisis pemahaman guru.pdf

Sapsuha, M. T. (2013). Pendidikan Pascakonflik: Pendidikan Multikultural Berbasis Konseling Budaya Masyarakat Maluku Utara. Yogyakarta: LKiS.

Suryana, Y., \& Rusdiana. (2015). Pendidikan Multikultural: Suatu Upaya Penguatan Jati Diri Bangsa Konsep, Prinsip dan Implementasi. Bandung: Pustaka Setia.

Tsuneyoshi, R., \& Okano, K. H. (2010). An interactive perspective for understanding minorities and education in Japan. In R. Tsuneyosh, K. H. Okano, \& S. Boocock (Eds.), Minorities and Education in Multicultural Japan: An Interactive Perspective. 1-272. DOI: https://doi.org/10.4324/9780203849194.

Winata, K. A., Ruswandi, U., \& Erihadiana, M. (2020). Konsepsi Pendidikan Islam terhadap Prinsip-Prinsip Multikultural di Sekolah. At-Ta'dib Jurnal Pendidikan Islam, 1(1), 51-70. DOI: https://doi.org/10.30863/ATTA'DIB.V1I1.741.

Zulaeha, I. (2013). Pengembangan Model Pembelajaran Keterampilan Berbahasa Indonesia Berkonteks Multikultural. LITERA, 12(1). 97-105. DOI: https://doi.org/10.21831/ltr.v12i01.1331. 